\title{
Yerusalem Tanah Suci Agama Samawi dalam Perspektif Hukum dan Perdamaian
}

\author{
Jawahir Thontowi
}

\section{Abstract}

The sincere confessing of Jerussalem as a holy land for three major religions would indicate new paradigm of peace issues through redefinement from absolute nationalism into relative Islamic nationalism.

\section{Pendahuluan}

Pernyataan Yasser Arafat untuk melakukan perlawanan secara militer terhadap pemerintah Israel, 22 Januari 2002 mengagetkan para pejabat Amerika. Kebijakan Arafat untuk merubah 200.000 polisi menjadi militer tidak diragukan keberadaannya dalam kaitannya dengan persiapan pelaksanaan perang terbuka. Tuduhan pemerintah Israel dan Inggris terhadap Arafat dianggap sebagai pelanggar ketentuan perdamaian karena menggunakan kekerasan, tampaknya tidak lagi dihiraukan. Tidak sukar memahami mengapa akhirnya
Arafat memilih ingin mati syahid atas perjuangan ini, karena terbukti Israel tidak melaksanakan perdamaian.

Lebih menyedihkan adalah ketika Israel saat ini terus menggempur wilayah Ramalah dengan alteleri berat. Termasuk Bandara Udara International menjadi sasaran tembak.Adian Husaini menyimpulkan KTT II antara Israel dan Palestina yang dipaksakan Presiden Clinton juga gagal. Lebih parah eskalasi kekerasan dilakukan oleh intifadah terus berlangsung. Upaya damai senderung semakin pupus sejak Arial Sharon yang garis keras itu berkuasa lagi. ${ }^{1}$

'Lihat "Israel Buldozer Bandara Gaza."Bandingkan dengan tulisan Adian Husaini. "Perdamaian Palestina." Harian Republika Sabtu, 12 Januari 2002. 
Jika dilacak akar-akar persoalan konflik di Palestina, maka tidak saja terkait persoalan kekuasaan, politik, dan nasionalisme. Lebih penting dari itu terkait dengan lingkaran sejarah agama-agama besar yang meletakkan Yerusalem sebagai tanah suci (Holy Land). Klaim masyarakat Arab muslim, Yahudi dan Kristiani terhadap Yarusalem tampaknya sama-sama memiliki bukti. Sejarah Nabi dan rasul-rasul seperti Adam, Ibrahim, Sulaeman, Daud, Isa dan Muhammad memiliki rangkaian penyaluran spiritual di Yerusalem. Namun, mengapa umatnya saat ini terus terlibat konflik.

Apabila disadari, klaim teritorial atas Yerusalem yang berlebihan tidak perlu terjadi jika umat Islam dan umat Yahudi kembali pada ajaran agama yang sebenarnya. Pemilikan atau penguasaan atas tanah atau kedaulatan teritorial didalam ajaran Islam tidak absolut, bahkan lebih bersifat amanah.Benarkah Yerusalem sebagai tanah suci umat Islam ataukah sebagai tanah suci bersama agama Samawi. Adakah relevansi antara perubahan paradigma berpikir umat Islam mengenai Yerusalem terhadap penciptaan suasana masyarakat global yang tertib, aman dan damai.

\section{Masjidil Haram: Tanah Suci Umat Islam}

Asal-usul fungsi Masjidil Haram bagi umat Islam begitu jelas dan tegas, yaitu sebagai tanah suci umat Islam di dunia. Pertama, Masjidil Haram menjadi pusat arah umat Islam dalam menghadapkan jiwa dan raganya dalam shalat. Penetapan Qiblat tersebut merupakan jaminan mengenai kepastian hukum ibadah shalat. Hal ini baru terjadi setelah pembatalan arah kiblat dari Palestina ke Masjidil Haram. Al-Qur'an menegaskan sebagai berikut :
"Kami saksikan betapa gelisahmu dengan menghadapkan muka ke langit, Kami sungguh akan mengarahkan kamu ke Qiblat yang kau sukai. Maka arahkan kiblatmu ke Masjidil Haram. Dimanapun kamu berada, arahkan wajahmu kepadanya. Ahli Kitab pasti tahu bahwa perpindahan itu betul-betul hak yang hilang dari Tuhan mereka dan Allah sama sekali tidak lupa segala yang mereka lakukan". (Al-Baqarah; 144).

Dari ayat di atas, terdapat tiga persoalan penting yang perlu dibahas secara komprehensif. Bagaimana umat Islam dapat memahami bahwa Masjidil Haram tanah suci umat Islam dunia. Perubahan arah Kiblat mengandung kepastian hukum bagi perubahan, terdapat segi-segi penting dalam ibadah, shalat dan haji.

\section{Kepastian Hukum untuk Beribadah}

Memperhatikan surat Al Baqarah ayat 144152 , khususnya mengenai perubahan arah qiblat dari Yerussalem ke Ka'bah di Masjidil Haram telah menimbulkan perdebatan yang cukup menarik di kalangan ahli-ahli hukum Islam. Akan tetapi, perdebatan itu terbukti tidak keluar dari konteks dan fungsi adanya kepastian hukum bagi umat Islam ketika melaksanakan shalat dan ibadah haji. Terdapat dua golongan yang mempersoalkan apakah perubahan arah qiblat tersebut merupakan preseden hukum pembatalan (nasikh dan mansukh) terhadap ketentuan hukum sebelumnya.

Golongan pertama berpendapat bahwa perubahan arah qiblat ke Mekah bukan merupakan preseden hukum pembatalan 
hukum, melainkan lebih merupakan penegasan untuk kepastian hukum semata. Pandangan ini dianut oleh Abdullah Yusuf Ali dan Muhammad Assad. Abdullah Yusuf Ali menegaskan bahwa Qiblat ke arah Ka'bah seagai ketentuan final telah memperlihatkan validitas hubungan antara Islam dan asal-usul pembangunan agama monotheisme Ibrahim. Keyakinan akan kebenaran Islam tidak saja disadarkan kepada wahyu, melainkan terdapat kesamaan esensial dengan agama yang hanif seperti yang dianut Nabi Ibrahim. Dalam pengetahuan masyarakat pra-Islam, kata-kata Hanif dipertentangkan dengan praktek-praktek ibadah yang politeistik, seperti berhala-hala yang ada di Ka'bah. Oleh karena itu, agama yang Hanif seperti yang dianut oleh $\mathrm{Nabi}$ Ibrahim menganut keyakinan agama tauhid. ${ }^{2}$

Muhammad Assad menegaskan perubahan arah kiblat dari Jerusalem ke Ka'bah di Masjidil Haram hanya merupakan kekosongan atau kebingungan di kalangan umat Islam. Perubahan ini terjadi sesudah umat Islam hijrah ke Madinah, dalam situasi umat Islam terorganisasi secara baik. Muhammad Assad berpendapat bahwa, meskipun pada masa Nabi fungsi Ka'bah dijadikan tempat penempatan berhalaberhala, secara historis ka'bah tetap diyakini sebagai tempat peribadatan yang paling kuno. Oleh karena itu, sejak enam belas bulan setengah setelah hijrah dan bertempat tinggal di Madinah, Nabi menerima wahyu yang menetapkan secara pasti Ka'bah sebagai Qiblat umat Islam.
Golongan kedua, seperti Imam Satibi dalam Al-Itqan dan ulama-ulama lain yang dikutip dari Yusuf Ali, mengakui perubahan qiblat dari Yerussalem ke Ka'bah di Mekah merupakan suatu pembatalan hukum. Hal ini berarti tradisi yang diberlakukan kepada Yahudi dan Nasrani tidak dapat diberlakukan bagi umat Islam meskipun semula merupakan tradisi. Asas hukum yang diberlakukan yaitu ketentuan khusus menyalahi ketentuan umum. ${ }^{3}$

Secara faktual tradisi yang berkembang dalam masyarakat Yahudi dan Nasrani mendorong Nabi untuk selalu munajat atau bermohon agar diberi petunjuk dan kepastian dan dihilangkan keraguan.

Yusuf Ali menggambarkan pandangan yang jelas mengenai alasan mengapa Nabi selalu menengadah ke langit. Keadaan yang dialami memperlihatkan hasrat yang ikhlas dari nabi untuk mencari insprasi mengenai persoalan arah Qiblat. Sampai dengan struktur organisasi umat terbentuk secara rapi, dengan perbedaan hukum dan ketentuan, hanya mengikuti praktek berdasarkan fakta yang telah menjadi tradisi Yahudi dan Nasrani yaitu menghadap ke Yerusalem sebagai tanah suci.

Selain kesucian Masjidil Haram ditentukan oleh Ka'bah sebagai simbol kesatuan arah umat Islam juga kesucian Masjidil Haram memberikan kepastian bagi umat Islam ketika Allah mewajibkan umat Islam melakukan ibadah haji. "Beritahukan kepada umat manusia, supaya mengerjakan haji mereka datang kepada engkau,dengan jalan kaki, dan

'Lihat Muhammad Asad. 1984. The Message of the Qur'an: Translated and Explaned. HIm 29.

'Dalam prinsip hukum umum, kasus pembatalan seperti termasuk pada asas hukum Lex Sepecialis derogat lexgeneralis. 
dengan berkendaraan seperti unta, mereka itu datang dari berbagai penjuru bumi." (Al-Haj: 28)

Masjidil Haram ditetapkan sebagai kesatuan Qiblat, terkait dengan penghormatan ajaran Islam terhadap beberapa peristiwa besar sebelum dan sesudah Nabi Muhammad lahir. Sebelum Nabi lahir, Masjidil Haram dijadikan tempat bersejarah bagi kelangsungan Nabi Ibrahim, Siti Hajar, Sarah dan Ismail. Sejarah kehidupan mereka ini dijadikan landasan sosiologis bangsa Arab untuk menjadikan hukum kebiasaan.

Islam hadir memperkuat dan merubah baju hukum kebiasaan atas ziarah ke Masjidil Haram menjadi kewajiban agama bagi setiap Muslimin. Kewajiban Haji selain merupakan tahap ibadah makdhah yang memerlukan pengorbanan jiwa, raga, dan harta, juga penghormatan terhadap peranan sejarah $\mathrm{Nabi}$ Ibrahim. Dalam bahasa lain, Haji merupakan Memorial Service, yang diwujudkan dalam bentuk perjuangan yang dimulai dengan Niat Ikhram, Thowaf, Sa'i, dan Wukuf. Dengan demikian kepastian penetapan Masjidil Haram sebagai tempat ibadah sholat, sekaligus menetapkan haji sebagai kulminasi identitas dan kualitas seseorang.

\section{Perubahan sebagai Ujian}

Umat Islam akan tetap setia dan patuh pada Nabi atau tidak ketika ada perubahan hukum. Hal ini tergantung kepada seberapa jauh kesadaran dan kecintaan umat Islam untuk mematuhi Nabi sebagai utusan Allah. Sebab kedudukan Jerusalem sebagai tempat suci dimana praktek peribadahan Yahudi dan Nasrani merupakan bagian dari tradisi dan adat istiadat Arab. Karena itu, amatlah wajar jika umat Islam tidak akan mudah melepas begitu saja untuk menghadapkan arah Qiblat dari Masjidil Aqsho ke Masjidil Haram. Allah berfirman:

Argumen ini terkait dengan ayat berikutnya, antara lain bahwa, "ahli-ahli kitab (Yahudi, Nasrani) tidak akan mengikuti atau mematuhi perubahan kiblat tersebut. Kehendak Nabi yang dikabulkan Allah tersebut sebagai putusan yang benar dan adil. Sebab setiap umat memiliki kiblatnya masing-masing" (AI-Baqarah-148).

Ujian ini tentu terkait dengan betapa perubahan nilai seperti terjadi masa Nabi tidak akan mudah diterima. Tradisi agama-agama sebelum Islam untuk mengarahkan mukanya ke Masjidil Haram, bertentangan dengan tradisi bangsa Arab ketika itu. Putusan perubahan itu menjadi tidak mudah, namun karena kejujuran Nabi, maka perubahan itu telah menembus sekat-sekat emosional kesukuan (begitu banyak suku di jazirah Arab) diganti dengan keyakinan Islam sebagai agama yang memberikan petunjuk pada jalan yang benar. Sebuah hadits yang disampaikan oleh Abu Said Al-Khusdri menegaskan, yaitu Nabi bersabda: ${ }^{4}$

Nabi Noah akan dipanggil pada hari kebangkitan dan ia menyatakan saya akan datang atas panggilan-Mu dan saya patuh atas perintahmu ya Allah. Allah berkata, akankah Engkau menyampaikan misi

${ }^{4}$ Bisa dibaca terjemahan Kitab Sahih Bukari. Jilid 6 no.14 
Islam sebagai agama Tauhid. Noah menjawab, ya. Selanjutnya ia ditanya, Apakah ia menyampaikan misi Tauhid kepadamu. Mereka menjawab tidak, tidak ada pernyataan kepada kami. Kemudian Allah berkata kepada Noah, Siapa yang akan menjadi saksi yang setia? la mengatakan Muhammad saw dan pengikutnya. Kemudian mereka akan diuji, apakah ia menyapaikan pesan Tauhid dan utusan Allah akan menjadi saksi karenanya. Kami ciptakan kamu sebagai muslim dan pengikut Nabi yang sebenarbenarnya, yaitu orang-orang yang beriman kepada Islam sebagai agama Tauhid, pengikut Nabi besar Muhammad yang sebenarnya.

Keberhasilan umat Islam untuk menerima perubahan arah kiblat dan Rasulnya membuktikan kekuatan Islam di Madinah semakin solid terutama karena kepatuhannya.

Asumsi ini berarti juga tidak konsisten sama halnya ketika umat Islam telah menetapkan arah kiblat tidak secara otomatis mewakili inti keimanan sebab Timur dan Barat adalah kepunyaan Allah. Konsekuensinya, orang-orang yang benar-benar taqwa tidak bergantung kepada apakah muka mereka menghadap ke Barat atau ke Timur (2:177). Wahyu yang menetapkan Ka'bah sebagai kiblat bagi kaum muslimin juga menjadi persoalan yang menimbulkan perdebatan bagi umat agama lain. ${ }^{5}$
Sekitar 1984, upaya yang ingin menodai Masjidil Haram telah berulang kali. Peristiwa perubahan arah kiblat yang semula dianggap ujian terbukti tidak mampu menggoyahkan keyakinan umat Islam di Madinah. Selain Ka'bah ditetapkan sebagai Qiblat, yaitu tempat yang paling kuno dan terkait dengan Ibrahim yang secara tradisional terkait pula dengan cerita awal kehidupan Nabi Adam. Peristiwa serupa juga terjadi ketika Nabi Muhammad berangkat untuk melakukan Isra dan Mi'raj dari Masjidil Haram ke Yerusalem sampai dengan Sidratul Muntoha. ${ }^{6}$

Meskipun terdapat perbedaan pandangan mengenai keberangkatan Nabi Muhammad dalam melakukan Isra' dan Mi'raj, jumhur ulama, menyebutkan Ka'bah di Masjidil Haram adalah tempat pemberangkatan dan Yerusalem tempat persinggahan.

\section{Yerusalem Tanah Suci Agama Samawi}

Yerusalem merupakan tanah suci bagi agama-agama samawi dapat dipahami, misalnya, surat Al-Baqarah ayat 148 berbunyi:Setiap umat punya kiblat yang mereka hadapi. Maka berlomba-lombalah dalam menebar kebajikan.

Bilamana realitas sejarah menggambarkan adanya agama-agama besar dan diakui eksistensinya oleh kaum Muslimin dari dulu hingga kini, maka ini juga harus berarti umat Islam mengakui adanya tempat suci bagi agama-agama besar. Ketika Allah

5Lahat Muhammad Assad. 1984. The Message of The Qur'an; Translated and Explained Gibraltar. Dar-Al-Andalas. HIm. 31.

${ }^{6}$ Menurut Lapedus, kedua tempat tersebut boleh jadi dijadikan sebagai pusat orang-orang saleh dalam memperoleh inspirasi. Lapedus. 1992. Him 216. 
menetapkan Ka'bah di Masjidil Haram sebagai tempat suci hanya untuk umat Islam, maka tentu Alqur'an juga tidak melupakan adanya tempat suci yang dapat diklaim oleh agama-agama samawi yang pernah lahir di Timur Tengah. Terlepas dari ada atau tidaknya dasar hukum, kenyataannya umat manusia mengetahui adanya tempat suci agama-agama. Misalnya, India termasuk tempat suci agama Hindu dan Budha. sedangkan Vatikan tempat suci agama Kristen dan Khatolik. Bahkan kedudukan Vatikan telah dijamin kepastian hukumnya berabad-abad. Kota ini dijamin kedudukannya oleh pemerintah Italia,dalam rangka menyebarkan misi keagamaan. Vatikan sebagai kota suci umat Kristiani ditetapkan melalui perjanjian anatara Pemerintah Italia dengan Pemimpin Gereja. Perjanjian ini dibuat tahun 1929 dan dikenal sebagai Lateran Treaty. ${ }^{\text {? }}$

Pemilikan bersama atas Yerusalem bagi bangsa Palestina sebenarnya mengisyaratkan adanya kemungkinan adanya pemilikan bersama, yang dalam konteks sejarah kehidupan umat manusia bukanlah sesuatu yang mustahil. Hipotesis itu akan menjadi berlebih-lebihan bilamana tidak memiliki argumen. Karena itu ${ }_{i}$ menjadi amat penting dan vital untuk dibuktikan apakah kata-kata yang berbunyi setiap ummat memiliki arahnya dan hukumnya masing-masing juga bisa menunjukan adanya pengakuan tanah suci agama-agama. Pemahaman tersebut, menarik pandangan Yusuf Ali bisa mengindikasikan Yerusalem tetap sebagai tanah suci, dala konteks masa lalu; tetapi sebagai agama yang progresif Islam dengan simbol yang barunya dapat mengenang tradisi masa lalu yang hampir mati. "Yerusalem still remained (and remais) sacred in the eyes of Islam on account of its past, but Islam is a progressive relegion, and its new symbolism enabled it to shake off the tradition up dead past and usher in the era of untrammelled freedom dear to the spirit of Arab". Penetapan Qiblat sebagai arah bagi umat Islam, kebanyakan dalam sejarah klasik dan kebanyakan moderen sebagai simbol ogarnisasi pemersatu. $^{8}$

Ibnu Kathir sebagaimana dikutip dari Muhammad Assad menerangkan kata "setiap umat memiliki arah kiblat", hampir seluruh ahli tafsir sepakat bahwa ayat itu menunjuk adanya berbagai komunitas agama-agama yang memiliki model dan bentuk peribadatan kepada Tuhan. Dalam hal ini, Ibnu Kathir menekankan bahwa tafsir yang sebenarnya yaitu "setiap umat kami tunjuk hukum dan tatanan hidup". Karena itu setiap umat memiliki arah Qiblatnya, sebenarnya merupakan upaya manusia untuk mendekatkan diri kepada Allah, sebagai tanda kepatuhan dirinya kepada Allah, menunjukan pertama, dalam keanekaragaman waktu dan dalam situasi yang berbeda, hasrat manusia mendekati Tuhan dalam saat muncul dalam berbagai bentuk. Misalnya: Ibrahim memilih Ka'bah sebagai kiblat, sedangkan Yahudi konsentrasi ibadahnya ke

'Lihat Malcolm N Shaw. 1997. International Law. Fourth Edition. Cambridge. Cambridge Unversity Press. HIm. 172.

${ }^{8}$ Ibid Yusuf Ali: 57. 
Yerusalem, yaitu kearah bagian Timur dari model gereja Kristen.

Menurut Ahmed Osman, ayat ini ditafsirkan sebagai : Alasan-alasan mengenai mengapa Yerusalem disebut sebagai tanah suci. Pertama, Yerusalem merupakan kota Nabi Daud, yaitu kota suci tiga agama, Yahudi, Kristen dan Islam. Pemukiman pertama Yerusalem kembali pada zaman batu, ketika penduduk membikin rumah di goa-goa, yaitu sekitar tiga ribu tahun sebelum masehi. ${ }^{9}$ Untuk mengetahui seberapa jauh Yerusalem sebagai tempat suci agama Samawi, bisa dilihat dari dua persoalan. Peŕtàma, peranan suku bangsa Semit dan Kedua, pendekatan bahasa atau asal usul Yerusalem. Dan geopolitik letak Yerusalem dalam konteks hukum dan politik.

\section{Semit sebagai Rumpun Besar Pemeluk Agama Samawi}

Untuk memperlihatkan bukti sejarah ayat kauniyah bagaimana status Yerusalem sebagai tanah suci agama Yahudi, Kristen dan Islam tercermin dalam pembangungan sejarah peradaban umat manusia. Setidaktidaknya ada tiga faktor yang menetukan status hukum Yerusalem menjadi tanah suci umat beragama. Pertama, peranan ekspansi Kaisar Sargon di wilayah Sumeria, Babilon dan Mesir, yang terlihat dari kemampuan kaisar Sargon dalam memainkan peranan cikal-bakal bangsa Semit, suku bangsa lainnya seperti Aromaik dan bangsa Arab. Ekspansi dominan terutama itu ditentukan oleh penyebaran penduduk di wilayah-wilayah Timur Tengah sekitar Jordania, Aman, Syiria dan Mesir. Dalam sejarah klasik Mesir Kuno tergolong bangsa yang telah memberikan kontribusi besar terhadap hukum. Raja Babilonia, bernama.Hamurabi tergolong peletak batu pertama tradisi hukum tertulis. Dan dari situ pula sistem hukum pidana pembalasan ditumbuh kembangkan hingga zaman moderen. ${ }^{10}$

Ahli sejarah, Toybee mencatat, Yerusalem acapkali menjadi perebutan dewasa ini tidak terlepas dari ekspansi dan penjajahan penguasa-penguasa politik. Masalah Kaisar Sargon sebagai penguasa klasik yang cukup berpengaruh dan memiliki kaitan dengan keberadaan raja-raja Babilonia setelahnya, sekitar tahun 2371-2316 sebelum Masehi. Kekuasaan mereka ketika itu berpusat di sekitar wilayah sungai Tigris dan Euprat. Penyebaran penduduk juga tidak bisa dilepaskan dengan orang-orang yang menggunakan bahasa seperti Hebrew, Aramian dan Arab. Toybee menyebutkan bahasa Semit ini memiliki hubungan keluarga

9Studi mendalam mengenai Yerusalem sebagai tempat lahirnya dan bertemunya para Nabi telah dilakukan oleh Ahmed Osman dalam bukunya 1992. The House of The Messiah: Controversial Revelation on The Historical Yesus. Glasgow: Harper Collin Publisher. HIm. 125.

${ }^{10}$ Teori sistem hukum pidana, seperti dikenal dalam agama-agama Samawi, mata dengan mata telinga dengan telinga (hukum Qishash) diperoleh dari hasil temuan arkeologis 1901 di Persia. Pelacakan peristiwa sekitar 2000 tahun sebelum Masehi. Lihat C.G.Weeramantry. 1975. The Law in Crisis: Bridges of Understanding.London: Capemoss. HIm 258 
dengan bahasa di Afrika Utara, seperti bahasa Kopti di Mesir, bahasa Turki dan bahasa Aramaie di Syiria dan bahasa Hebrew di Palestina."

Dari segi penyebaran penduduk Michael Avi Yonah, yang melakukan penelitian enam abad sebelum dan enam abad sesudah Masehi, menyimpulkan bahwa Yerusalem, sebagai kota suci pernah dihuni oleh bangsa penduduk dengan agama yang berbeda-beda. Tetapi, perbedaan itu muncul sebatas, agamaagama Semit yang berkiblat pada Ibrahim. "Sejarah yang mengesankan mengenai tanah suci dari periode Persia ke Byzantium direfleksikan dengan komposisi penduduk di berbagai wilayah dan perubahan-perubahan yang berkaitan persoalan waktu.

Disatu pihak penyebaran orang-orang Yahudi melalui pemukiman di beberapa tempat di Beersheba, tetapi mereka ini lenyap ketika orang-orang Persia berkuasa. Di dipihak lain, pemukiman orang-orang Yahudi memperluas pemukimannya kearah barat pantai dan kearah pengunungan di wilayah utara. Pemukiman yang menyebar dan sisanya dari sepuluh suku Israel yaitu di Galitee, di Gilead dan tanah Tabiad di Jordan.

Di wilayah pantai selatan dihuni oleh masyarakat Palestina dan Palestina Syiria. Lebih menarik dari itu, ketika periode Byzantium, memang diakui betapa banyaknya pengaruh dari perpindahan dari negara- negara kristen. Sejak itu, Kristen, Yahudi dan Helenisme berlansung untuk saling bercampur didalam suatu tempat untuk upacara keagamaan.

Ahli-ahli agama dan penghuni-penghuni datang dari Italia, dari Asia Minor, Yunani, Iberia, Mesir dan negara-negara Afrika. Mereka inilah bermukim utamanya disekitar Yerusalem. Sekitar setengah abad lebih sejak Isa lahir, penduduk Yahudi di Yerusalem menurut catatan Josephas, sekitar 270.000 an. Meskipun jumlah itu diragukan kesesuaian umlah yang semestinya harus dipenuhi dalam melakukan perpindahan menurut kitab suci ada kecocokan. Sedangkan catatan kedua, Bar-Hebraus, dibawah kekuasaan Claudius, jumlah Yahudi sekitar 6.944.000 an. ${ }^{12}$

Pengaruh budaya, bahasa dan penyebaran penduduk yang begitu besar umumnya juga diakui sebagai potensi bagi pertumbuhan sebuah bangsa. Bangsa yang ada di Timur Tengah, Afrika dan sebagian Asia tidak bisa menolak adanya intervensi bangsa Semit. Lebih penting dari itu, kehadiran tiga agama, Yahudi, Kristen dan Islam dewasa ini merupakan refleksi dari interaksi budaya yang terjadi di Yerusalem dan sekitarnya.

\section{Yerusalem Sebagai Wilayah Damai}

Analisis kedua yang perlu dikemukakan Yerusalem sebagai tanah suci agma-agama

"Lebih detil lihat penjelasan komprehensif Toynbee. 1976. Mankind and Mother Earth. Norfolk: Oxford University Press. HIm. 67.

12Studi yang mendalam mengenai perimbahan penduduk yang tinggal di Yerusalem dilakukan oleh Michael Abi-Yonah. The Holy land. From The Persian To Arab Conquest (536 B.C. - A.D. 640) 
samawi itu terkait dengan nama Yerusalem yang memiliki muatan wilayah damai. Sebagian konsekuensi dari ekspansi kekuasaan raja-raja Sargon ke wilayah lain, ternyata analisis bahasa memang masih relevan dalam menentukan wilayah damai. Benar dan tidaknya padanan bahasa juga bisa dipahami dari segi Yerusalem dalam kancah politik intenasional, sebagai netralized country, negara yang dinetralisasi oleh negara-negara sekitarnya. Bisa dilihat dari bukti letak geografis dan sejarah dan ekspansi kekuasaan.Ada penafsiran bahwa Yerusalem disebut tanah suci karenaYerusalem merupakan kota Perdamaian, "Yerusalem, City of Peace".

Didalam Arab Moderen, Yerusalem dikenal sebagai AI-Quds, atau ha-Qudesh dalam Hebrew, yang artinya tanah suci (the holy ground). Penyebutan tanah suci itu berikutnya terkait dengan sejarah Nabi Daud membangun tempat ibadah, yang kemudian diikuti Caud Sulaeman. Begitu juga Nabi Ibrahim telah memperoleh kebahagiaan dari tanah sebagai rahmat dari Tuhan pencipta langit dan bumi. Dengan kata lain penyebutan Yerusalem sejak zaman Ibrahim sebagai tanah suci, bukan sekedar didasarkan pada penduduk kota itu, tetapi juga bagi orang-orang Palestina, dan namanya sendiri Yerusalem sebagai Qudesh.

Sedangkan Yerusalem secara leterik, bisa dikaitkan dengan makna perdamaian dipengaruhi oleh beberapa faktor. Pertama, Uru, Yara (jamak), dirikan atau bangun sedangkan salim atau shalom yaitu damai atau patuh. Kata lain seperti Urusalim atau Yerusalem itu jadi berarti cikal bakal perdamaian atau membangun perdamaian. Pengambilan arti seperti itu memperoleh dukungan dari bukti sejarah. Sebagaimana sumber-sumber di Mesir, kata Qadesh, seperti digunakan dalam kitab Injil dan Qur'an adalah sama artinya dengan Yerusalem.

Kesesuaian tafsir melalui bahasa apakah benar bahwa Yerusalem itu kota suci bisa dikaitkan dengan fakta sejarah. Diantara catatan sejarah dari Thuthmosis III, disebutkan bahwa ratusan nama-nama tempat di Palestina umumnya masuk wilayah kampanye dari pertikaian. Palestina Selatan tampaknya ditawarkan tidak ada pertahanan militer, di wilayah utara antara Gaza, Damaskus, Timur Tengah, dan di Timur Sungai Jordan, Yerusalem disebut Baital Maqdish karena tidak pernah dijadikan untuk persengketaan.

Bersandarkan kepada fakta, Raja Yerusalem, yaitu Abdi Kheba, Dinasti ke delapanbelas, yang membayar upeti untuk mematuhi tradisi damai dengan Piraun. Sama halnya dengan France di deklarasi sebagai Paris sebagai kota terbuka dalam Perang Dunia Kedua sebagai jaminan supaya tidak dihancurkan oleh kekuatan Hitler.

Bilamana Yerusalem ketika itu dijuluki sebagai tempat suci atau damai ditandai oleh adanya pengecualian letak Yerusalem. Yang perlu dijamin kenetralitasnya. Letak geografis, Yerusalem yang perlu dinetralisasi itu merupakan kebutuhan dan pintu gerbang ke arah Laut Timur Tengah dan Arabia. Terutama bagi negara-negara yang mau melakukan transaksi perdagangan impor dan ekspor. Dalam hukum internasional, letak Yerusalem ini bisa dianalogikan dengan situasi Switzerland di benua Eropa. Negara tersebut termasuk negara yang dinetralisasikan melaluj suatu perjanjian internasional sejak perang dunia pertama.

Dalam hukum internasional; negara yang netral dengan negara yang dinetralkan 
memiliki perbedaan yang tajam. Negara yang netral (tidak memihak) yaitu suatu negara yang dilarang atau tidak tidak memberikan dukungan terhadap salah satu pihak yang sedang konflik senjata. Larangan itu terutama terkait dengan sarana dan prasarana yang biasanya dipergunakan dalam peperangan.

Sedangkan negara yang dinetralisasi yaitu suatu negara yang dijamin keberadaannya oleh negara-negara tetangga untuk dijamin keberadaan pemerintahannya untuk tidak memihak kemanapun, baik dalam keadaan perang maupun dalam keadaan damai. ${ }^{13}$

Pertama, bahwa dari segi antropologi politik, maka keputusan Allah untuk memindahkan arah kiblat ke Ka'bah tidak lain sebagai "balance of power" (keseimbangan kekuatan) antara kedaulatan agama Islam dengan umat Yahudi. Sehingga pertikaian agama seminimal mungkin dapat dihindari dan harmoni sosial dapat dipertahankan.

Untuk kepentingan harmoni dan keputusan politik, Sultan Abdul Malik, yang menggantikan kedudukan kekuasaan Islam pada abad ke-8,setelah Abdul Azis, juga mendukung klaim umat Yahudi bahwa Yerussalem adalah tempat pertama kalinya Ibrahim mendirikan tempat ibadah. Untuk memberikan pengakuan, maka Abdul Malik mendirikan masjid di Yerussalem dengan menyediakan satu ruangan yang ditembok sebagai pertanda maqam Ibrahim. Prof. Lapedus, dalam History of Islamic Societ- ies mengatakan: The Dome of the Rock was built in the most sacred city of Judaism and Christianity in order to sygnity the political and religious appropriation of the past by a new faith embodied in a new empire (Lapedus, 1991: 85 ).

Tindakan Abdul Malik dipandang sebagai toleransi atas kesepakatan politis dan hukum. Dimana Perdamaian untuk hidup bertetangga antara umat Islam yang baru berkuasa dengan umat Yahudi yang baru saja dikalahkan harus lebih diutamakan.

Silih bergantinya kekuasaan di. wilayàh sekitar Yerusalem, dari kekuasaan Raja Persia, Byzantium dan Islam terus berjalan secara berulang. Sekitar akhir abad ke sembilan yaitu ketika buku yang ditulis Theodore Herzl, 'The Jewish State' Negara Yahudi 1896, merupakan kelangsungan konflik yang meruyak dan berkembang hingga kini. Pembangunan negara Yahudi dengan gerakan zionismenya tampaknya telah membangkitkan sentimen negeri-negeri Arab untuk memusuhinya ideologi zionism, yang mengklaim Yerusalem sebagai tanah leluhur Yahudi juga telah membangkitkan semangat nasionalism. Upaya mendirikan negara Zionis Yahudi menuntut tidak saja penguatan ideologi negara, melainkan juga upaya penambahan penduduk yang lebih besar. Konsekuensi dari kampanye zionis ini telah menumbuhkan sentimen dan diskriminasi kepada umat Islam. Gerakan zionisme ini sebenarnya tidak identik

${ }^{13}$ Lihat tulisan Michael Akhurst. 1983. A Modern Introduction to international Law.Fourth Edition. Sydney: George Allen \& Unwind. HIm. 241. Untuk kepentingan keseimbangan kekuatan (Balance of Power), Switzerland dan Belgia dijamin untuk terhindar dari serangan militer melalui perjanjian internasional 1815 dan 1839, him 218. 
dengan gerakan Yahudi. Namun, karena zionisme bagian dari Yahudinya, umat Islam mempersepsikan mereka tanpa batasan yang tegas. ${ }^{14}$

Semangat nasionalisme yang mengembangkan Yerusalem sebagai rumah di negeri-negeri Arab menjadi sumber konflik internal keluarga agama-agama samawi. Integritas teritorial yang menjadi salah satu kedaulatan negara menggiring penggunaan kekerasan "menyerang (attack) atau bertahan (defense)" menjadi paradok dalam meruntuhkan nilai-nilai perdamaian. Klaim negara Yahudi tersebut mengakibatkan terjadinya penolakan penduduk Arab yang tinggal di Yerusalem. Semangat Yahudi ini mendapatkan dukungan dari penjajah Inggris, yaitu dikeluarkannya deklarasi Belfour yang dikeluarkan oleh Inggris.

Deklarasi ini pada dasarnya menghendaki agar negara Yahudi di Yerusalem terbentuk sebagai suatu administrasi pemerintahan tersendiri: Namun, gagasan terbukti telah menimbulkan konflik oleh karena Inggris tidak memperhitungkan kehadiran negara-negara Arab. Liga bangsa telah berusaha mengesahkan mandat kepada Inggris agar Yerusalem dapat diberikan administrasinya. Kebijakan lain yaitu ketika Inggris mengijinkan bagi Yahudi untuk melakukan imigrasi, membeli tanah, bahkan mengijinkan mereka buat organisasi politik. Sikap pemihakan itu tampaknya sama dengan ini tentu saja sangat sensitif kebijakan diskriminatif antara AS dengan Inggris dewasa ini. ${ }^{15}$ Akibat dari adanya kristalisasi pembentukan negara yang berkebangsaan Yahudi, negara-negara Arab Muslim pun ikut mengedepan resistansi termasuk perlawanan Mulits. Semangat nasionalisme yang dimiliki oleh orang Islam tanpa batas telah menimbulkan pemahaman yang tidak tepat atas kedudukan Yerusalem. Sebagai tanah suci agama-agama Samawi, Yahudi, Kristen dan Islam. Dalam hal ini kata Islam, yang sama dengan salam juga berarti penyerahan atau kepatuhan terhadap Keimanan Tuhan. ${ }^{16}$ Islam sebagai agama dan pandangan hidup yang mengandung nilainilai perdamaian menjadi tidak efektif ketika pemahaman komprehensif tidak didapatkan oleh umat Islam dan juga umat agama lainnya.

\section{Simpulan}

Dari paparan di atas dapatlah disimpulkan bahwa perubahan arah atau Qiblat ke Ka'bah di Masjidil Haram telah memberikan pemaknaan akan kepastian hukum bagi perbedaan status Masjidil Haram dari Yerusalem. Disatu pihak Masjidil Haram secara simbolik sebagai tanah suci umat Islam. Status ini ditentukan selain oleh fungsinya

${ }^{14} \mathrm{Kritik}$-kritik tajam dan komprehensif mengenai gerakan zionisme yang menimbulkan efek negatif bagi kaumYahudi bisa dibaca tulisan Yehoshafat Harkabi. The Meaning of A Democratic Palestinian State, Di dalam Roberts S Wistrich.The Left Against Zion: Communism, Israel and The Midle East. London: Vallentine Mitchell. HIm 236-247.

${ }^{15}$ Sejarah Arab dan Islam yang terkomplit. Lapidus. 1991. "A History of Islamic Societis". Ira. M. Lapidus Cambridge: Oxford University Press. Hlm. 659.

${ }^{16}$ Lihat penjelasan Ahmed Osman. 1992. The House of The Messiah : Controversial Revelations on The Historical Jesus. Glasgow: Harper Collin Publisher. HIm. 125-134. 
sebagai pusat penyatuan arah ibadah shalat dan haji, juga mengandung tanda-tanda bagi pembenaràn asal-usul pertumbuhan agama Hanif atau Tauhid Nabi Ibrahim. Konsekuensinya, adalah kegamangan yang selama itu dialami Rasulullah berakhir dán menjadi petunjuk yang benar mengenai pusat peribadatan.

Di pihak lain perubahan arah Qiblat ke ka'bah di Mekah tidak mengurangi makna kesucian tanah suci di Yerusalem. Namun, umat Islam perlu berjiwa besar untuk mengakui Yerusalem sebagai tanah suci bagi tiga agama besar seperti, Yahudi, Kristen dan Islam. Surat Al-Baqarah ayat 145 dan Hadish Buchari dan Said Al-Hudri merupakan dasar hukum yang dapat mengakomodasi adanya beberapa tempat untuk menjadi tanah suci, sebagai arah dari model pelaksanaan ibadah agamaagama yang ada.

Adapaun kedudukan Yerusalem sebagai tanah suci bagi agama-agama samawi, bukan saja mengandung bukti-bukti fungsional atas Yerusalem sebagai pertemuan spiritual NabiNabi Daud, Ibrahim, Sulaiman, Musa, Isa dan Muhammad, melainkan juga • makna kesejarahan bagi nilai-nilai perdamaian. Dalil mengenai Yerusalem sebagai tanah suci yang secara fungsional terkait dengan perdamaian,bukan saja berpangkal tolak dari segi analisis bahasa, melainkan juga disandarkan kepada fakta Yerusalem secara geografis. Peranan penting dari suku bangsa Semit baik karena ekspansi budaya dan bahasa, dan letak geografis amat strategis nampaknya mengharuskan Yerusalem dijadikan wilayah damai, dengan cara adanya perjanjian negara-negara tetangga untuk menetralisir Yerusalem.
Pengakuan ikhlas dan tulus untuk menetapkan Yerusalem sebagai tanah suci milik bersama tiga agama dapat mengindikasikan timbulnya paradigma baru mengenai perdamaian, yaitu melalui upaya meredefinisi semangat nasionalisme absólut menjadi nasionalis Islam yang relatif. Pembelaan atas klaim Yerusalem sebagai tanah suci umat Islam, tampaknya perlu mulai ditinggalkan ketika kehendak perdamaian dibicarakan. $\square$

\section{Daftar Pustaka}

Avi-Yonah, Michael. 1976. The Holy land. From The Persian To Arab Conquest. 536 B.C.-A.D.

Akehurst, Michael. 1983. A Modern Introduction to international Law. Fourth Edition. Sydney: George Allen \& Unwind.

Asad, Muhammad. 1984. The Message of the Qur'an: Translated and Explained.

Assad,. Muhammad. 1984. The Message of The Qur'an; Translated and Explained. Gibraltar, Dar-Al-Andalas.

Harkabi, Yehoshafat. The Meaning of A Democratic Palestinian State.

Husaini, Adian."Perdamaian Palestina." Harian Republika. Sabtu 12 Januari 2002

Lapidus. The Left Against Zion: Communism, Israel and The Midle East. London: Vallentine Mitchell.

Muhammaf Yusuf Ali. Holy Alqur'an: Texs and Interpretation.

Muhammad Taqiyyuddin Al-Hilaly. 1995. Alqur'an: The Texs and Explanation. Saudi Arabia. 
Osman, Ahmed. 1992. The House of The Messiah: Controversial Revelations on The Historical Jesus. Glasgow: Harper Collin Publisher.

Shaw, Malcolm N, 1997. International Law, Fourth Edition. Cambridge. Cambridge Unversity Press.

Toynbee, Arnold 1976.. Mankind and Mother
Earth. Norfolk: Oxford University Press.

Weeramantry, C.G. 1975 The Law in Crisis:

Bridges Of Understanding, London, Cape Moss.

Wistrich, Roberts S. The Left Against Zion: Communism, Israel and The Midle East. London: Vallentine Mitchell.

—. Kitab Sahih Bukari. Jilid 6 no.14.

Zaini Dahlan. 1999. Alqur'an dan Terjemahan. Oleh Yogyakarta: UII Press. 